\title{
Study on the Layering Teaching Model in College English
}

\author{
Danting Sui \\ Jiangxi Institute of Fashion Technology \\ Nanchang, China
}

\author{
Fenghong Li \\ Jiangxi Institute of Fashion Technology \\ Nanchang, China
}

\begin{abstract}
Teaching students in accordance with their aptitudes is a basic principle in pedagogics. Therefore, English teachers in colleges might as well implement the layering teaching according to students' real levels and requirements. The thesis mainly discusses the layering teaching from its construction and implementation.
\end{abstract}

Keywords—college English; layering teaching; teaching model

\section{INTRODUCTION}

\section{A. Students' Study Situation}

After the college entrance examination, China's students will begin to learn their major courses in the college. English as a required course has also being learned. Except for English majors, students in other majors usually have different English levels and foundation, especially for art students. I will take the first-year students in Jiangxi Institute of Fashion Technology as an example.

In 2016, the college enrolled nearly 1646 new students and the full mark of the college entrance exam in English is 150 points. The number of students who got scores more than 90 points is about 491, taking up 29.83\%; the number of students who got scores between 90 points and 60 points is about 597, taking up $36.27 \%$; the number of students who got scores less than 60 points is about 558, taking up 34.00\%. We can see clearly from the following "Fig. 1".

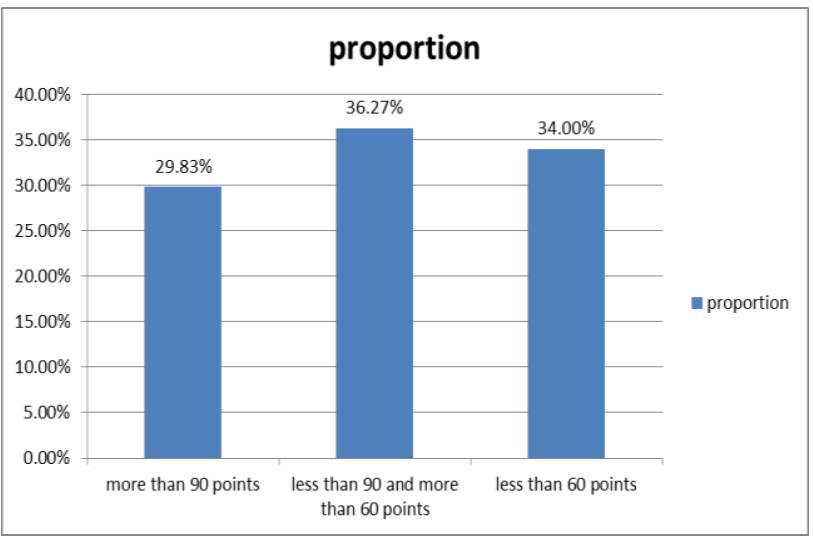

Fig. 1. Proportions of students with english scores.

Fund:The thesis is within the teaching-reform research of Jiangxi provincial projects (Grant No.JXJG-16-26-10)
From the above, we know students' English level is not the same. The students have different English levels in each class no matter how many students are in each level as well as different English learning basis.

\section{B. Teaching Situation}

Working as an English teacher in the college for 10 years, I feel it's rather difficult to meet the needs of all students in the same class. That's because not only the art students' English foundations are weak, but also they have different English levels. Though they have learned English since they were in the primary school, they seldom speak English in the public or at home. English as a foreign language, students just learn and improve it by their own efforts without using environment. That is one of the reasons why students' English levels are different. Although we do not want to admit, but the fact is the case. Students with good English tend to master the language points easily and are eager to learn more, while students with poor English can not keep up with good ones. Students with fair English have their own learning speed and acceptable abilities. It's obvious that students with different levels should learn the knowledge which varies in difficulty levels, but it's impossible for the teacher to take care of different knowledgerequired students in the same class at the same time.

The quality of foreign language teaching should be paid more attention. When the higher education has stepped into the mass education, teaching quality is certainly becoming a major concern. It also includes foreign language teaching. Foreign language is a useful tool of communication. It is a basic course, but it will affect students' future employment and selfdevelopment in the global world. Teachers and colleges better stress on the foreign language teaching.

\section{The Necessity of Layering Teaching}

As has been mentioned above, how to balance different levels of students' English is becoming an obstacle in teaching and studying. The teacher may as well try to take layering teaching model to solve the problem.

Layering teaching could satisfy needs from different levels of students. After layering, the same or similar level of students study together in the same class. These students have similar basis, so they could learn at the same rate. If the students could follow the others, they would have more confident to learn without giving up. Meanwhile, the layering teaching makes the teaching have a strong purpose and pertinence. Teachers could 
just prepare the lesson for one level of students, rather than spending more time and energy on different levels.

\section{LAYERING TEACHING MODEL's CONSTRUCTION}

\section{A. Theory Basis}

Confucius, a famous educator in China, advocated teaching students in accordance with their aptitudes. It's one of important methods and principles in the process of teaching. Each individual is differently qualified. The cognitive levels, learning ability and their own quality are varied from one student to the other. Their different study habits, foundation, interests and capacities should be considered while teaching. The teacher chooses varied teaching methods for every student to develop their strengths, stimulate their interests, establish their confidence and promote their all-round development.

Howard Gardner proposed multiple intelligences in his 1983 book Frames of Mind. In the theory, there are eight intelligences: musical-rhythmic, visual-spatial, verbal-linguistic, logical-mathematical, bodily-kinesthetic, interpersonal, intrapersonal, and naturalistic. According to Gardner, intelligence is "a bio-psychological potential to process information that can be activated in a cultural setting to solve problems or create products that are of value in a culture."[1] A single general ability defining a person is too narrow. Just because the traditional education system heavily focused on intelligence quotient, verbal-linguistic ability and scores, teachers always taught different students the same materials in the same way and treated students as the same individual. Actually, we can achieve our goals through many ways. Individuals differ in the strength of these intelligences. Students' different and strong intelligences should be invoked and combined to carry out different tasks, solve diverse problems, and learn properly.

Layering teaching based on the students' existing knowledge, ability levels and potential tendency, the teacher divides the students into several groups with similar levels and treats levels differently. For different levels, teaching methods and strategies are used according to the real situation. Layering teaching is to recognize and consider students' different intelligences, aptitudes as well as different English levels, and try to teach them by their strong aptitudes and intelligences.

\section{B. Layering Teaching's Principles and Model}

Layering teaching is based on the students' foundation, levels, interests and requirements. That is, it centers on the students. The college had better consider whether the students need English course or not. The purpose of learning a foreign language is to communicate in the wide world and is good for people's future life and job. Besides English, many other languages can open for non-English majors to select. In the view of students' needs, our college offers Korean and Japanese courses at present.

The main principle in layering teaching is that the students have the right to choose. They can choose which language they want to learn and which English level class they want to be in. In order to guide students select the language and level properly and smoothly, the second principle is they have the right to know. They must be told that their decision should be made on their real study condition, the features of each language and each level, the general requirements of the courses, the learning and teaching targets and so on. Of course, the teacher will certainly give them possible and reasonable advice. The third principle is that every student should make a selection. Only in this way can they get the corresponding credits. If they really don't want to learn a foreign language, they can choose an extra major course instead of the language course upon request.

The teaching model is a more stable framework of teaching activities and procedures under the guidance of certain teaching theories, connecting teaching theories with teaching practice. It is not only the application of teaching theory, but also a direct guide to teaching practice. What should the teaching model be in the layering teaching? Setting out from the teaching purposes and theories, students' characteristics and requirements as well as combining the teaching conditions, the front-line experienced teachers have put forward the following teaching model "Fig. 2":

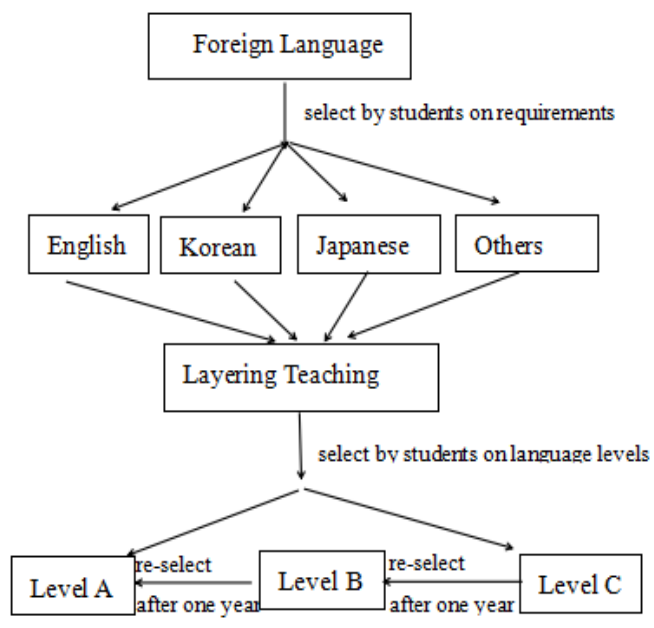

Fig. 2. Layering teaching's model.

This teaching model abides by the layering teaching's principles and tries to improve the teaching effectiveness. In the model, many languages will be offered. Students can select one of them through their real interests and future needs. There are three levels in each language. Relatively speaking, level A is the highest level for the students who master the language better than others. Level B is lower than level A and level C is the lowest. Though there are three levels, it doesn't mean the students in level $\mathrm{C}$ are the worst students, however, it just shows that these students' English foundations are not as good as others and the teachers need to make great efforts to consolidate their foundations, invoke their interests in language learning. It is essential that teachers can't divide students into bad ones and good ones by levels. The fact is that for each level the teachers should make concrete targets, use proper methods and organize appropriate activities and so on.

We all know that nothing is perfect. This model will be perfected in the teaching practice. 


\section{LAYERING TEACHING MODEL'S IMPLEMENTATION}

\section{A. Model's Implementation}

Layering teaching is carried out by keeping to the model as seen in the "Fig. 2" when new students enter the college and the courses will open for two years. In our college, the leaders strongly support this new attempt. After one year preparation, the layering teaching began in 2016. In practice, we took the following operation procedures:

1) Propaganda work began when the new students participated in military training. Our college foreign language teachers introduced to students how many foreign languages taught in the college, the features of these languages, how many levels in each language, classification criteria at each level and what they could learn in each level. In order to let the same level of students study together, each level will be regulated by the scores of the college entrance exam. Scores are just for reference. If the student who got lower scores than usual for some reasons and was sure to keep up, he also could choose higher levels.

2) After propaganda, the students made their decisions and selected the corresponding course or level in the coursesselected system. The timetable and classroom can be viewed in the system. Since the foreign language course is compulsory, to make sure all the students attend the course at the same time, the Academic Affairs Office arranged foreign language course ahead of other courses in the timetable. After selecting, the same level of students could learn in the same class.

3) The teacher prepared the lessons, set up relevant teaching goals, adopted the proper teaching methods and assigned the tasks according to the level of students. Such teaching is more effective and targeted. The most important is almost students could keep up with the teacher since the students' English is at the same level.

For the students who were enrolled in 2016, the layering teaching has been successfully implemented. At present, there are one Korean class, one Japanese class and forty English classes including 7 levels-A classes, 12 level-B classes and 21 level-C classes.

During the teaching, different teaching materials are used for different levels. We do like this, because we consider the students at different levels should get different learning abilities through learning.

\section{B. The Survey of Students' Satisfaction}

In June 2017, after the layering teaching has been taking for one year, the foreign language teachers conducted a questionnaire survey on students' satisfaction with their studies. The survey covers 7 levels-A classes and 5 level-B classes.

The main survey questions are:

- Could you accept and support the layering teaching?

- Can you keep up with the teacher in level-A or level-B class?

- Will you switch into other classes?
There are nearly $85 \%$ students like this teaching model, but some students worry that teachers and other students will look down upon lower-grade students. All students say they will not switch into another class and if they make their efforts they can keep up with the teacher.

In order to get more feedback in the teaching, five foreign language teachers were interviewed. One of them teaches levelA class, two of them teach level-B classes and the other two teachers are in charge of level-C classes. The main interviewed questions are:

- How about the students' attendance?

- How do students behave in class?

All the teachers say the students' attendance is very good. The students in level-A and B classes and some of level-C students behave more actively; however, some level-C students take a cavalier attitude to learn.

Although the survey just covered some classes but not all, from the survey results, we see clearly that most of the students are satisfied with this teaching model and show great concern for learning, especially for level-A and B students. Minority level-C students are not interested in learning.

This survey also tells us the students with better language skills got more motivation in different level class. Besides it, all students wanted to get credits through foreign language course rather than substitute major course, showing they know foreign language can help them in the future and the importance of mastering a foreign language. In addition, we should pay more attention to level-C students' study situation. How to encourage them to learn and arouse their study interests become one of the main researches.

After one year, we will take another survey. At that time, 2016 students will have finished their foreign language study. In other words, the first round of layering teaching will be done. We will conduct an all-round and full coverage questionnaire survey.

\section{REFLECTION}

The layering teaching has been carrying out just for one year and it will be still going on in our college. Though it's at the initial stage, most of the students support this teaching attempt. No matter what the attempt is, don't forget the original intention. The purpose of this new attempt is to help students find what they want, what they can learn and how to learn from the perspective of students' intelligences and requirements.

In this practice, there are some deficiencies, so we could improve our teaching and teaching model by following measures:

1) Learn more teaching theories and further understand the layering teaching: The layering teaching has been carrying out in the primary and high schools for many years and educators or teachers have accumulated a lot of experience from it. However, this kind of research in colleges is not very common. We don't have much referential experience. We had 
better to read more books and theses on teaching and layering teaching.

2) Find a better way to introduce the courses and levels: This time, teachers just introduced the courses and levels by verbal words. These abstract words may pass through some students' mind so fast that they didn't understand it at all. How to avoid this kind of problem? Next time, we will adopt multimedia technology. We are planning to make the course introduction into 5-10 minute micro-learning resource. It will be more intuitive for students to understand what the features of the course are, how to select the course as well as the layering teaching in the college.

3) Consider carefully about the teaching materials used in the layering teaching: Before attempting the layering teaching, our foreign language teachers had already communicated with other college teachers who have already carrying out layering teaching for some time, like Nanchang Institute of Science\&Technology and Pingxiang University. In these colleges, they use the same material for different level students, but their teachers integrate this material, putting forward different teaching objectives and teaching the same content with different levels in difficulty. Which is better for students and teaching? The same material or the different material? This requires teachers' further consideration and practice.

4) The final examination should be reformed: The purpose of examination is to test the students' mastery of the knowledge they've learned. Therefore, there's no need to abolish the examination. However, how to organize the test and how to test the students' true abilities are real challenges. In our final exam, we've made a bit of reform. Besides the exam paper, we take students' attendance, behavior on class and foreign languages' competition into consideration. Each section has a certain score. Students want to get higher scores in this kind of exam, they need give more enthusiasm and take part in class activites and other competitions more actively. In fact, students do perform like this. But that may not be enough, we need more improvements.

\section{CONCLUSION}

The purpose of layering teaching practice in our college is to construct a practical and effective teaching model, stimulate students' interest in learning foreign languages and improve teaching quality. Layering teaching has already been very popular in primary schools and high schools, but it is seldom used in colleges. Though this thesis mainly discusses the layering teaching in the college from its construction and implementation, not all aspects, I hope it can provide a kind of teaching reference and practical guidance for the majority of teachers.

\section{REFERENCES}

[1] Gardner, Howard, Intelligence Reframed: Multiple Intelligences for the 21st Century, Basic Books, 1999, P33-34

[2] Albanese,M. A.\& Mitchell,S. Problem-based Learning:A Review of Literature on its Outcomes and Implemengation Issues[J].Acad Med,1993,Vol.68(l)
[3] Wilkins, D.A.. Linguistics in language teaching[M].London: Edward Amold,1972 